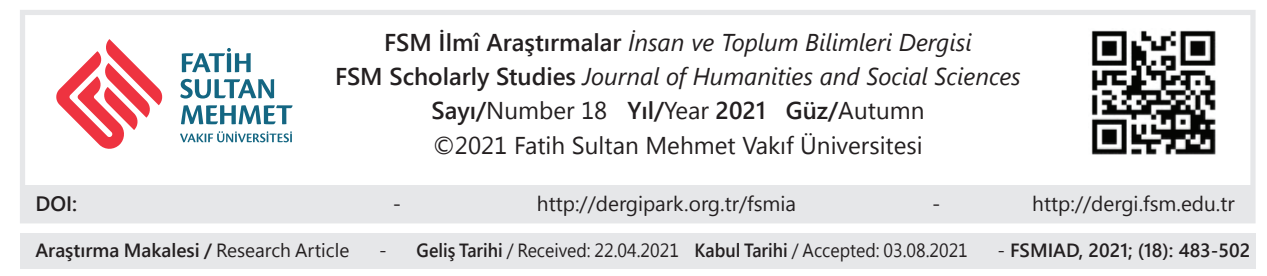

\title{
Endüstrinin Estetik Arayışı: Minton, Hollins \& Co. Üretimi İznik Desenli Sırlı Duvar Karoları
}

Timur Bilir

\section{$\ddot{O} z$}

19. yüzyılın ilk yarısında İngiltere'de başlayan ve kısa sürede tüm Avrupa'ya yayılan Sanayi Devrimi döneminde belediye binaları, hastaneler, tren istasyonları, okullar, müzeler ve kütüphaneler gibi kamu binaları inşa edilmiş ve kaplama malzemelerine talep artmıştır. Mermer ve taş zeminlere ucuz ve zarif bir alternatif olan seramikler, bu yapıların ve yeni oluşan orta sınıfın konutları için üretilmiştir. Karoların dekorasyonu için köklü kültüre sahip olan ülkelerin sanatlarından ilham alınmıştır. Tüm dünya müzelerinin en seçkin koleksiyonları arasında yer alan Osmanlı çini ve seramikleri de bunların arasındadır. Bu makalede, seramik endüstrisinin gelişmesinde önemli bir role sahip olan Minton, Hollins \& Co. firması tarafından üretilen karolardaki İznik desenleri araştırılarak değerlendirilmiştir.

Anahtar Kelimeler: Duvar karoları, Sanayi Devrimi, Minton Hollins \& Co., İznik.

\footnotetext{
* Doç., Mimar Sinan Güzel Sanatlar Üniversitesi Geleneksel Türk Sanatları Bölümü, İstanbul/ Türkiye, timur.bilir@msgsu.edu.tr, orcid.org/0000-0003-0873-5354.
} 


\title{
Industry's Quest for Aesthetics: Minton, Hollins \& Co. Production of Iznik Patterned Glazed Wall Tiles
}

\begin{abstract}
During the Industrial Revolution, which started in England in the first half of the 19th century and spread all over Europe in a short time, public buildings such as municipal buildings, hospitals, train stations, schools, museums and libraries were built and the demand for coating materials increased. A cheap and elegant alternative to marble and stone floors, ceramics were produced for the residences of these structures and the nascent middle class. For the decoration of the tiles, the arts of countries with deep-rooted cultures were inspired. Ottoman tiles and ceramics, which are among the most distinguished collections of all world museums, are among them. In this article, Minton, Hollins \& Co., which has an important role in the development of the ceramic industry, Iznik patterns on the tiles produced by the firm were investigated and evaluated.
\end{abstract}

Keywords: Tile, Industry Revolution, Minton Hollins \& Co., Iznik. 


\section{Giriş}

19. yüzyılın ilk yarısında İngiltere'de yer ve duvar karosu üretimi, endüstriyel alandaki gelişmeler ve bilimsel yöntemleri kullanmanın üretimi hızlı ve uygun fiyatlı kılacağı konusunda hemfikir olan girişimci iş adamlarının gayretiyle hızla artmıştır. Bu durumun sosyal nedenleri arasında inşaat alanında yığma yapılar yerine mimaride değişen anlayışa bağlı olarak cam, demir ve seramik kullanımının artmasının yanı sıra, 1831-32 ile 1848-49 y1llarında yaşanan kolera salgınları bulunmaktadır. Salgınlarla birlikte hijyen konusunda farkındalık artarak üst sınıf konutların planlarına kapalı tuvalet, banyo ve sıhhi tesisat dahil edilmiştir. ${ }^{1}$ Doktorlar ve mimarlar, banyo, mutfak ve yiyecek mağazaları gibi sürekli temiz tutulması gereken yerlerde kolayca temizlenebilen seramiğin kullanımı konusunda halkı bilinçlendirmiştir. Büyük felaketlere neden olan şehir yangınlarına karşı önlem olarak yanıcı özelliği olmayan seramiğin mimaride kullanımı kampanyasına şehir planlamacıları da dahil olmuştur. İngiltere, 1850 yılında Avrupa'nın en güçlü ve dünya çapında en büyük etkisi olan ülkesiydi. Bu dönemde endüstri çağının modern kent yapısına uygun olarak belediye binalar1, hastaneler, okullar, oteller, tren istasyonlar1, müzeler ve kütüphaneler gibi yeni kamu binaları inşa edilmiş ve kaplama malzemelerine talep artmıştır. Buhar enerjisiyle çalışan gemilerle ticaretin hızlı ve güvenli olması, kaplama seramiklerinin Avrupa'nın her köşesine ve Amerika'ya ihraç edilmesini sağlayarak büyük bir pazar oluşmuştur. Staffordshire bölgesindeki Stok-on-Trent, seramik endüstrisinin gelişmesinde başı çekmiştir. Kuzey Staffordshire, seramik endüstrisinin ihtiyacı olan kil, kurşun, tuz ve kömürün yerel olarak mevcudiyeti nedeniyle 17. yüzyılın başlarında seramik üretiminin merkezi haline gelse de bölgedeki seramik kültürünün varlığı çok daha eskilere dayanmaktadır. ${ }^{2}$ 19. yüzyılda bölgedeki irili ufaklı yüzlerce üretici, sofra takımlarından dekoratif parçalara ve endüstriyel ürünlere kadar geniş yelpazede seramik üretmiştir. Bölge atölyeleri earthenware, stoneware ve porselen üretiminin yanı sıra kemik porseleni (bone china), jasperware gibi yeni gövde yapıları ile transfer baskı gibi birçok dekor tekniğinin gelişmesinde de öncü olmuştur. ${ }^{3}$ Staffordshire seramikleri genel olarak orta ve düşük fiyat aralıklarında üretilmesine rağmen, en yüksek kalitede ve pahalı ürünler de üre-

1 Wendy Harvey, "A Brief History of Transfer Printed Tiles", Transferprint Collectors Club Bulletin, vol. xii, no. 1, 2011, p. 17-19.

2 John Thomas, “The Pottery Industry and The Industial Revolution”, Economic History, vol. 3, no. 12, February 1937, p. 399-414.

3 Josiah C. Wedgewood, Staffordshire Pottery and It's History, London, S. Low, Marston \& Company Limited, 1913, p. 1. 
tilmiştir. Başta Josiah Wedgewood olmak üzere Joel Spode, Thomas Minton, Wood Family ve Thomas Whieldon gibi 18. yüzyılın diğer ünlü imalatçıları, bölgenin seramikle anılmasını sağlamıştır. "Çömlekçiler" adı ile anılan Tunstall, Burslem, Hanley, Stoke, Fenton ve Longton adlı altı kasabadan müteşekkil bölge, 1817 başlarında tek bir idare altında birleşme kararı almıştır. Yönetimde teşkilatlanma 1857 'de başlamıştır. 1910 'da bu kasabalar birleşerek Stok-on-Trent idari bölgesini oluşturmuştur. 1925 yılında eyalet statüsü elde eden Stoke-on-Trent, bugün de İngiliz seramik endüstrisinin merkezi ve dünyanın en büyük seramik merkezlerinden biridir.

\section{Endüstri Çağı İngilteresinde Kaplama Seramikleri Üretiminin Gelişimi}

19. yüzy1lda kaplama malzemeleri sadece mimari yüzeylerde değil, sandalye ve koltuklar, dolaplar, şömineler gibi yerlerde geniş kullanım alanı bulmuştur. Kaplama malzemesi üretim teknolojisi, mermer ve taş zeminlere ucuz ve zarif bir alternatif sağlamak için geliştirilmiştir. Bu karolar, ilk etapta üst sınıf kamu binaları ve dini yapılar, ikinci etapta Viktorya dönemi orta sınıf konutlarının iç dekorasyonu için üretilmiştir. ${ }^{4}$ Siparişler müşterinin isteğine göre firma kataloglarında bulunan hazır desenlerden ya da bütçeye göre özel olarak tasarlanıyordu. Kilise restorasyonu projeleri, üreticilere hazır bir pazar sunmuştu. Zemin kaplamalarının tasarımları, ortaçağ örnekleri üzerinden geliştirilmiştir. Birkaç renk farklı kilin bir arada kullanılmasıyla üretilen kakma karoların (encaustic) seri üretim patentini 1830'da Stok-on Trent'den Samuel Wright almıştır. ${ }^{5}$ Karo sanayisinin önde gelen isimlerinden Herbert Minton, hem iç hem de dış piyasadan aldığ 1 çok sayıda siparişi zamanında yetiştirebilmek için Wright'ın vidalı pres ile üretim patentini 1835 'te satın alarak seri üretime geçmiştir. Fakat üretimde standardizasyon için kil karışımları, fırınlama dereceleri, çamur küçülme oranları gibi konular üzerinde beş yıl daha çalışmak gerekmişti. 1840 ve 1850 'lerin başlarında Minton \& Co. tarafından üretilen karolar, iki büyük buluş ile karakterize edilir. Bunlar, kilin toz presleme yöntemi ile şekillendirilmesi ve seramik üzerine çok renkli baskı yapılmasını mümkün kılan blok bask1 tekniğidir. Herbert Minton,1840'da Birmingham'l1 bir mühendis olan Richard Prosser'in seramik kulpların toz haline getirilmiş kilin preslenmesi ile

4 Lesley Durbin, "Nineteenth Century Tiles. Industrial Mass Production and Construction Methods of Interior Tile Schemes in the Nineteenth and Early Twentieth Centuries", Architectural Tiles Conservation and Restoration From the Medieval Period to the Twentieth Century, New York, Routledge, 2011, p. 989-991.

5 Aygül Uçar, Karosiman : İzmir Konutlarında Döşeme Karoları, İzmir, İzmir Büyükşehir Belediyesi Kent Kitaplı̆̆ı, 2015, s. 27. 
üretimi için geliştirdiği teknolojinin mozaik yer karoları ve sırlı duvar karolar1 üretiminde kullanılabileceği potansiyelini fark ederek patentin bir hissesini satın almıştır. Toz preslemeyle karo üretimi(dust-pressed), geleneksel plastik kille üretime göre çok avantajlıydı. Büyük bir presle vasıflı iki operatör, günde 1200 'den fazla karo üretebilmiştir. Üstelik bu teknik, plastik kille üretim sürecinde yaşanan deformasyon ve kuruma süresini bekleme gibi dezavantajları da ortadan kaldırarak mükemmel karo üretimini sağlamıştır. ${ }^{6} 1860$ yılına kadar yaygın olarak tüm yer karoları, uzun bir süre alan yaş ya da plastik kil kullanılarak üretilmiştir. Prosser'ın geliştirdiği teknikte kil kurutularak öğütülüyor ve sadece $\% 5$ ila 8 oranında nem içeriyordu. Daha önceleri üç santim olarak basılabilen karoların et kalınlığı, bu teknoloji ile bir santime kadar düşürülebilmişti. Toz presleme teknolojisinin hem yer hem de sırlı duvar karoları üretimini arttırmasıyla mimaride seramik kullanımı zirve dönemini yaşamıştır.

Karo işçiliğinin ev dekorasyonunda yaygın olarak kullanımı 1870-1890 arasındaki dönemdir. ${ }^{7}$ Toz pres tekniğiyle üretilmiş beyaz gövdeye sahip sırlı duvar karoları, yer karoları endüstrisiyle birlikte gelişmeye başladıysa da popülerlik kazanması, teknik zorluklardan dolayı uzun zaman almıştır. Hem düz, hem de kabartmalı karoların büyük çoğunluğu bu teknikle üretilmiş, ancak özel ve büyük parçaların üretiminde plastik kil kullanılmıştır. Karolar birçok farklı türde dekore edilmiş̧ir. Bunların en yaygın olanları sır altı boyama, mayolika, derin kabartma, blok bask1, transfer baskı ve astar akıtma olanlardır. Mayolikada dekor, kalay oksitle opaklaştırılmış sır üzerine uygulanılmıştır. Derin kabartmalı karolar, sırın kabartma girintilerinde koyu renkler oluşturmasını sağlayarak bir yüzey üzerinde iki ton etkisi yaratmıştır. Astar akıtmada ise desenin dış hatları astarla kabartılarak oluşan hücrelerin içine uygulanan renkli sırların birbirine karışması önlenmiştir. Karoları elle dekorlamanın emek yoğun ve pahalı bir işlem olmasından dolayı, endüstriyel seramik üretiminde en büyük buluşlardan olan transfer bask1 tekniğinin erken denemeleri 18. yüzyılın ortalarında başlamıştır.

Transfer baskının ilk denemesi, Liverpool'lu baskı ustası John Sadler tarafindan Delft üretimi kalay sırlı karolar üzerine yapılmıştır. 27 Temmuz 1756 tarihli bir beyannamede, Sadler ve asistanı Guy Green'in altı saatte 1200'den fazla karo üzerine desen bastıkları belirtilmiştir. Tekniğin getirdiği yenilik, bakır levha üzerine oyulmuş desenin ince bir jelatin tabakası vasıtasıyla kalay sırlı karo üzerine aktarılması idi. Transfer baskı ile dekorlanan karoların çoğu siyah, kırmızı, mavi

6 Hans van Lemmen, 5000 Years of Tiles, London, British Museum Press, 2013, p. 172.

7 Lynn Pearson, "Decorative Tile and Terracotta Exports by British Manufacturers, 1840-1940", Journal of the Tiles\& Architectural Ceramics Society, vol. 11, 2005, p. 27-32. 
gibi renklerle tek renk olarak üretilmiştir. Sır üzerine yapılan baskılar 600-800 C gibi düşük bir ısıda firınlanmıştır. ${ }^{8}$

Transfer baskı tekniğini sır altına uygulayan ise, bone china adıverilen porselen türünü de geliştiren Josiah Spode idi. ${ }^{9}$ Bu teknikle doğrudan bisküvi pişirimi yapılmış gövde üzerine basılarak şeffaf sırla kaplanan dekor, seramiğin kendisi kadar uzun ömürlü hale gelmiştir. Spode, Stoke'da sır altı transfer bask1lı sofra takımları üretimini yaklaşık 1784 'de başlatmıştır. Şeffaf sır ile birlikte en başarılı netice veren pigmentlerin başında kobalt oksidin gelmesinden dolayı dekor sir alt1na mavi olarak basılmıştır. Transfer baskı tekniğinde iş akışı kısaca şöyledir: Bakır plakalardan alınan baskılar, özel bir kağıda basılarak seramik üzerine aktarılıyordu. Üzerine desen kazınarak işlenilmiş bakır plaka, yağlı boya karışımının oyulmuş hatlara daha iyi nüfuz etmesi için hafifçe isıtılıyordu. Boyası verilmiş bakır levha üzerine hafifçe nemlendirilmiş kağıt yerleştirilip gravür sehpasından geçirilerek kağıda basılıyordu. Desen basılan kağıt, transfer edileceği yüzey üzerine serilip kuvvetlice ovuşturularak karo ya da seramik form üzerine aktarılıyor ve ardından kağıt tabaka islatılarak sıyrılıyordu. Yağ tabakasının dekor pişirimi yapılarak yüzeyden uzaklaştırılması sağlanıyor ve ardından sırlama ve sır pişirimi yapılmak suretiyle üretim süreci tamamlanıyordu. 1784 ve 1833 yılları arasında Spode, sir altı transfer baskılı sofra takımlarının başta gelen üreticisi olmasına rağmen, daha az sayıda karo üretmiştir. Karolara talep daha az olduğundan bunlar için özel tasarımlara ihtiyaç duyulmayıp sofra takımlarının desenleri karoya uyarlanmıştır.

Minton'un transfer baskılı desenlerinin ilk örnekleri, bakır levhalara gravür tekniğinde işlenmiş "çiçek sepetleri”, "rustik figürler" gibi konularla mavi-beyaz olarak basılmıştır. 1848 'de F.W.M. Collins ve A. Reynolds seramik üzerine baskıda kullanılacak yeni bir yöntem geliştirmiş, Herbert Minton, Reynolds'un buluşunun sofra takımları ve karolara uygulanabileceğini öngörerek onu işe almıştır. Blok baskı (block printed) olarak bilinen bu yöntem, tasarımların her renk için ayrı hazırlanmış metal plakalardan kağıtlara basılarak karo ve seramiklere uygulanabilir hale gelmesini içeriyordu. Desenler çinko plaka üzerine kabartma olarak işleniyordu. Her renk için kabartma olarak bir plaka hazırlanarak, kaymayı engelleyecek bir çerçeve kullanılmak suretiyle aynı kağıt üzerine her renk plakası basılıyor ve sonrasında transfer baskı tekniğindeki aynı prosedür uygulanıyordu. Asıl yenilik, düz renkli alanların hem sır altı, hem de sır üstü olarak karoya

8 Hans van Lemmen, "From Over Glaze to Under Glaze : British Transfer Printed Tiles 17561854", Journal of the Tiles\& Architectural Ceramics Society, vol. 23, 2017, p. 1-10.

9 Ersoy Yılmaz, "Seramik ve Transfer Bask1 1750-1900", Sanat ve Tasarım Dergisi, 1(10), 2012, s. 93-111. 
uygulanabilmesiydi. Blok baskı tekniğini tasarımlarına en iyi uyarlayan sanatçı, Minton firması için sayısız yer karosu tasarımı yapan sanatçı A.W.N. Pugin'di. 1850'de Minton, Pugin'in tasarımı olan blok baskı tekniği ile dekorlanmış bir dizi duvar karosu üretmişti. Bu karolar, Westminister Sarayı'ndaki yabancılar sigara içme odasının dekorasyonunda kullanılmıştır. Ayrıca firma tarafından kurşun ve kalay oksitle opaklaştırılmış bir dizi kabartma dekorlu karo da üretilmiştir. Bunlar ilk olarak 1851'deki Büyük Fuar'da sergilenmiş ve South Kensington Müzesi yenileme odası bu çinilerle dekore edilmiştir. Yüzyılın başlarında kurşunlu sır kullanılmasına bağlı olarak görülen kurşun zehirlenmeleri üzerine kurşunlu sırlardan vazgeçilmeye başlanmıştır. Kurşunlu sırların hem işçi, hem de endüstri için zararlı olduğu kabul eden endüstri, alkali sır kullanımına dönmüştür. Alkali sırlar, kurşunlu sırlardaki kadar parlak renkler vermese de, zehirsiz olmaları onları tercih edilir kılmıştır.

\section{İslam Seramikleri’nin İngiliz Kültürü Üzerindeki Etkisi}

19. yüzyılda, Avrupalıların Oryantalizm merakı ve yeni pazarlar elde etme düşüncesi, birçok üreticiyi doğu kültürlerinin seramiklerini keşfetmeye itmiştir. Avrupa'nın pek çok saygın müzesinin en önemli koleksiyonlarını oluşturan Osmanlı çini ve seramikleri bunların başında gelir. Hızla gelişen ve üretim hacmi artan endüstrinin desen ihtiyacını karşılamak için üreticiler, bu konuda köklü geçmişi olan ülkelerin sanatsal geleneklerinden ilham almıştır. Müzelerin koleksiyonlarındaki karo ve seramikler ile yeni basılan resimli kitaplar, onlar için kaynak oluşturmuştur. ${ }^{10}$ Owen Jones'un 1842 'de yayınlanan Elhamra Sarayı'nın mimari birimleri ve süslemelerinin detaylı bir şekilde ele alındığı çalışması "Plans, Elevations, Sections and Details of Alhambra", İngiliz toplumunu İslam mimari geleneğinde çini ve kaplama malzemelerinin kullanım olanaklarıyla tanıştırmıştır. 1851'de İngiltere'de düzenlenen Crystal Palace olarak da anılan Büyük Fuar'da yer alan Elhamra Sarayı canlandırmasında Minton \& Co. firması üretimi olan çinilerin kullanılması, bu izlenimin daha da güçlenmesini sağlamıştır. Dünyanın tüm ülkelerinin endüstriyel ürünleri ve yeni buluşlarının tanıtıldığı bu fuar, mimaride demir, cam ve seramik kullanımının geldiği noktayı yansıtması açısından büyük önem taşır. 1860'ların başlarında eleştirmenlerin yazılarında, İslam dünyasına ait sırlı ve dekorlu karo kullanımının çok eski dönemlere dayandığı, İran, Mısır, Türkiye ve Hindistan'daki camilerde bunların en güzel örneklerinin görülebileceği belirtilmiştir. Hızla gelişen ve yoğun talep gören karo sektöründeki firmalar, 19. yüzyılın ikinci yarısında imar edilen kamusal alanlar-

10 Anette Hagedorn, “Orientleştirici Stilde Avrupa Cam ve Seramiğì", İslam 'da Bilim ve Teknik, (içinde), cilt 1, Ankara, Türkiye Bilimler Akademisi Yayını, 2008, s. 177-203. 
da kullanılacak karoların desenlerini tedarik etmek için bu dönemde yayınlanan kaynaklardan faydalanmıştır. 1837'de geliştirilen mekanik baskı tekniği kromolitografi ile basılan çok renkli ve kaliteli görsellerin yer aldığı kitaplar, dönemin tasarımcıları için başvuru ve ilham kaynağı olmuştu. Owen Jones'un Elhamra eseri bu tekniğin ilk kullanıldığı çalışmalardandır ve daha sonra yayınlanacak olan Arap, Türk, İran, Hint ve diğer ülkelerin tasarımlarının yer aldığı "Grammar of Ornament"ın temelini oluşturmuştur. Minton şirketinin ünlü tasarımcısı Christopher Dresser, bu seramiklerin süslemelerine olan hayranlığını "İran işleri kadar güzel süsleme görmedim" şeklinde ifade etmiştir. 1862 Londra sergisinde Minton firmasının İslami tasarımlardan etkilenen birkaç eseri sergilenmiştir. Bunlar arasında birkaç şişe, Dresser'a atfedilen bir bahçe koltuğu ve İznik modellerinden kopya edilen bir iki anonim parça vard $1 .{ }^{11}$

19. yüzyılın ortalarında İslam seramiği örneklerini görme firsatı bulmak zor olsa da, ilerleyen tarihlerde bu şans katlanarak artmıştır. Daha sonra Victoria \& Albert Müzesine dönüşen South Kensington Müzesi, bu seramikleri satın almanın öncülüğünü yapmıştır. 1862'de müze adına John Charles Robinson tarafından "İran işi” olarak nitelendirilen 51 parça satın alınmıştır. Robinson, yazısında bu güzel seramik türünün kökeni ve tarihi hakkında çok az şey bildiğini, fakat İran halıları, nakışları ve kitap süslemeleri ile ilişkilendirildiklerinde İran işine benzediklerini ifade etmiştir. Robinson, 1851 sergisinde Türk standında bu tür örnekleri görmesine rağmen bu görüşünden vazgeçmemiştir. ${ }^{12}$ Katalogladığı örnekler arasında parlak kırmızı, kobalt mavisi ve yeşil sır altı boyalarıyla renklendirilmiş lale, gül, sümbüllerle bezeli seramikler, günümüz bilgileri 1şığında onaltıncı yüzyıl Osmanlı dönemi İznik atölyelerine ait işlerdir. Hem endüstriyel fuarlardan çağdaş parçalar, hem de Robert Murdoch Smith ve Caspar Purdon Clarke vasitasıyla 1876'da Türkiye, Suriye ve Yunanistan'dan İznik seramikleri satın alınarak koleksiyon zenginleştirilmiştir.

Robinson ve karo üreticilerine göre Rodos'tan satın alınmalarına ithafen "Rodos İşi”" olarak tanımlanan bu tarz, "İran İşi” olarak kalmıştır. Rodos’ta Fransız konsolosu olan Auguste Salzman'a göre bu seramikler, Haçlılar tarafından ele geçirilerek buraya sürgün edilen İran'lı çiniciler tarafından lokal olarak üretilmiştir. C.D.E. Fortnum, South Kensington Müzesi için hazırladığı seramik kataloğunda

11 Sara J. Oshinsky, "Christopher Dresser (1834-1904)", In Heilbrunn Timeline of Art History, New York, The Metropolitan Museum of Art, 2000, p. 1-6.

12 Melanie Gibson, "Colouring the Surface : A Taste for Persian Tiles in English Domestic Architecture 1870-1914", Art, Trade and Culture in the Islamic World and Beyond, Gingko Library, 2016, p. 188-201. 
ilk olarak bu tarz seramikleri "İran İşi” yerine "Şam İşi”" olarak sınıflandırmıştır. ${ }^{13}$ Muhtemelen Suriye ve Türkiye üzerinden yaptığ 1 yolculuklardaki kişisel gözlemlerinin sonucu olarak bu kategoride kobalt mavisi, ada çayı yeşili ve turkuaz tonlarında çiçek desenli olan parçaları ve 1549 tarihli Kubbet-üs Sahra kandilini öne çıkan bir örnek olarak görmüştü. Bununla birlikte bu sınıflandırmalar, İran İşi adını benimseyen karo üreticileri tarafından kabul görmemiştir. Bu kültürel üstünlük, 1876'da Robert Murdoch Smith tarafindan South Kensington Müzesi'nde düzenlenen İran Sanatı sergisi ile güçlendirilmiştir.

George Augustus Sala, çok miktarda İngiliz ve Fransız çinilerinin sergilendiği 1867 sergisini incelerken 19. yüzyılda patlayan çini endüstrisinde İran İşi (Persian Ware) olarak adlandırılan Osmanlı ve Mağribi iç mekanlarının izlenimini veren çinilerin popüler olduğu yorumunu yaparak bu karoların yüzyılın sonlarında popülerliğinin zirvesinde olan Doğu tarzı sigara içme odalarının dekorasyonu için mükemmel olduğunu belirtmiştir. Çinilerin dekoru, İslami orijinallerinin aynısı olmakla birlikte, dönemin endüstriyel gelişimine özgü teknolojiyle üretilmiştir.

\section{Minton Kataloglarında Yer Alan İznik Desenli Çiniler}

1793'te Thomas Minton tarafindan kurulan Minton firması, hem seramik ürünler, hem de mimari kaplama malzemeleri alanında Viktorya Dönemi İngilteresi'nde lider konumundayd $1 .{ }^{14}$ Firma, bu itibarını seri üretimle ilgili müthiş bir öngörüye sahip olan girişimci işadamı Herbert Minton'a ve hem Ortaçağ' 1 klasik desenlerini, hem de yenilikçi tasarımları başarıyla yorumlayan sanatçılarla işbirliği yapmasına borçludur. Léon Arnoux, Walter Crane, Christopher Dresser, Augustus Welby Pugin, John Moyr Smith gibi birçok ünlü isim, değişik dönemlerde Minton için çalışmıştır. 1845'te Michael Hollins ile ortaklığa giren Minton, kiliseler, kamu binaları, özel konutlar için yer ve duvar kaplamaları üreterek pazarın önde gelen firmalarından biri olmuştur. 1793'ten 1968'e kadar düzenli faaliyet gösteren firmanın yer ve duvar karolarının yer aldığı kataloglar, müşteriler ve mimarlar için büyük kolaylık sağlıyordu (Resim 1,2).

1868'de Minton, Hollins \& Co. firması, mirasçıları Colin Minton Campbell'ın porselen bölümünü, Michael Dountry Hollins'in ise yer ve duvar karoları üretimini üstlenmesi ile ikiye ayrılmıştır. Hollins'in firması şirketin eski adını kullanırken, Campbell'ın başında bulunduğu porselen bölümü Minton’s China

13 Charles Drury Edward Fortnum, A Descriptive Catalogue of the Maiolica, Hispano-Moresco, Persian, Damascus and Rhodian Wares in the South Kensington Museum with Historical Notes, Marks \& Monograms, Chapman Hall, 1873, p. 25. 
Works adını aldı. Fakat porselen bölümü, karo da üretmeye devam edince aralarında çıkan anlaşmazlık, tasarımlar için patent alma zorunluluğunu getirmiştir. Kataloglarda bu desenler "patent tile works" olarak belirtilmiştir (Resim 3,4). Arşivlerde ilk alınan patent tarihi 1870, son alınan ise 1886 olarak tespit edilmiştir.

Şirketin arşivinde bulunan desenler Mart 2015'te Sanat Fonu tarafından, Stok şehrine bağışlanmıştır. Adı Minton olmakla beraber, arşivin kayıtlarında bölgeye ait yirmiye yakın üreticinin kayıtları bulunmaktadır. Koleksiyonun Minton kısmı, bu arşivin oluşturulmasında odak noktası olmuştur. ${ }^{15}$

19. yüzy1l sonlarında İngiltere'de kaplama malzemelerinde hakim olan Doğu modasını yansıtan tasarımlar, Minton firmasının her iki şubesinin ürünlerinde de (Minton's China Works ve Minton, Hollins \& Co.) kendini gösterir. Kataloglarda "Persian" olarak nitelendirilen bu desenler, Türkiye'deki İznik çinilerinin etkisini taşır. Şirketin desen arşivinde bulunan suluboya tasarımlardan birinin üzerinde, 1849-1892 yılları arasında firmanın sanat direktörlüğünü üstlenen Leon Arnaux tarafindan yazılan Fransızca notta 1858 ' de orijinalinin C.M. Campbell tarafindan Paris'ten satın alındığı belirtilmiştir. Yine başka bir örnek üzerinde "Konstantinopolis'ten eski çini, C.M. Campbell tarafindan getirilmiştir, Temmuz1873" notu, Campbell'ın İznik çinilerine olan ilgisini açıkça göstermektedir (Resim 5,6).

Türk çini desenlerine dayanan bu karolar, Minton, Hollins \& Co.'nun 18741875 yılları arasında yayınlanan kataloğuna dahil edilmiştir. Bu tarihe kadar şirket, İngiliz ve Avrupa kraliyet saraylarının yanı sıra, Osmanlı sultanının sarayını da içeren projelere karo tedarik ediyordu. Adıgüzel, Topkapı Sarayı'nda bulunan Avrupa çinilerini konu alan doktora tezinde, Herbert Minton'un yeğeni Colin Minton Campbell'ın Abdülaziz Av Köşkü'nün inşa edildiği yılda (1856) Osmanlı çinilerini incelemek üzere İstanbul'a geldiğini ve sarayın depolarında bulunan üç adet İngiliz üretimi çininin Campbell aracılığıyla gelmiş olma ihtimalini belirtmiştir. ${ }^{16}$

Mimar Thomas Ambler, Hertford House'in yeni sahibi Richard Wallace için eve yeni eklediği sigara odasına Minton kataloğundan karolar seçti. Seçilen iki desenin birinde içinde lale bulunan turkuaz renkli saz yaprakları ve spiral bir hareket yapan hatayi üslubunda çiçeklerden ulama desen duvarlar ve tonozlu tavanın döşemesinde, içinde karanfiller bulunan vazo ve selvi ağaçlı ulama karo ise süpürgeliklerde kullanıldı (Resim 7,8).

15 https://themintonarchive.org.uk.

16 Hatice Adıgüzel, “Topkapı Sarayı'ndaki Avrupa Çinileri’nin Üretim Merkezleri Işığında Değerlendirilmesi”, (Yayımlanmamış Doktora Tezi), İstanbul Üniversitesi Sosyal Bilimler Enstitüsü, İstanbul, 2014, s. 368. 
Almanya'nın Münih kentinde yer alan Bavyera Ulusal Müzesi, 1873 Viyana Sergisi sırasında, Minton firmasının 1870-71 kataloglarında yer alan İran tarzı adı yakıştırılan bu çinilerden bir dizi satın alınmıştır. ${ }^{17}$ Bunlardan bir kısmı İznik çinilerinin orijinallerinden birebir kopya edilmiş desenlere sahiptir (Resim 9,10). İlgi çeken bir diğer gurup ise, orta kısmında daire formunda alanlar ayırılmış olan ulama tarzındaki karolardır. Bu desenlerin aynıları, Minton firmasının seramik tabaklarında da kullanılmıştır. Hatayi üslubunda çiçekler ve hançer yapraklardan oluşan desene sahip olan bu karoların dairelerin dışında kalan alanları ise yine aynı üslupta bitkisel süslemelerle bezenmiş ve bu alanlar renklendirilmeden b1rakılmıştır (Resim 11).

Viktorya \& Albert Müzesi koleksiyonunda bulunan C238-1976 envanter numaralı Minton üretimi mavi-beyaz çininin deseninde 17. yüzyılın karakterini yansıtan çift tahrir tarzında hatayiler ile sarılma bulut motifleri bir arada kullanılmıştır. Yine aynı müzede yer alan C202.1976 envanter numaralı bir diğer çininin deseninde ise lale, karanfil ve haşhaş motifleri ile içi rumilerle bezenmiş olan şemseler görülmektedir. Açıklamalarında her iki karonun da toz presleme tekniği ile üretilip transfer baskı olarak dekorlandığı bilgisi yer almaktadır (Resim 12,13).

Gerrards Auction Rooms tarafından 2021 yılında açık arttırmaya çıkarılan ulama tarzındaki Minton çinisinin deseni, kapalı form rumi ve hatayi motiflerinden oluşmaktadır (Resim 14). Bilgi kısmında çinilerin kalıp kabartma olduğu belirtilmiştir. British Museum koleksiyonunda bulunan 1613615504 envanter numaralı bir çift ulama karo, $1 / 4$ katlamalı hatayi üslubunda motiflerden oluşan kompozisyona sahiptir. Açıklama yazısında çinilerin toz presleme ile üretilip transfer baskı olarak dekorlandığı bilgisi yer almaktadır (Resim 15).

Minton firması, İznik desenlerini sadece çini karolarda değil, seramik formlara da uygulamıştır. Resim 11'de görülen ulama karonun ortasında dairesel olarak ayrılmış olan alandaki kısım, tabak desenlerinde de kullanılmıştır. British Museum koleksiyonunda yer alan 1613269073 envanter numaralı sir altı dekorlu tabakta bu ulama karolardan birinin deseninin aynısı görülmektedir (Resim 16). Açık ve kapalı formlu kaplarda klasik İznik seramikleri form tipolojisi yerine, Çin vazosu formu üzerine "cloisonne" tekniği ile çalışılması gibi farklı kültürlerin sanat formlarını birleştiren eklektik uygulamalar yapılmıştır. Metropolitan Museum of Art koleksiyonunda bulunan Christopher Dresser tasarımı vazo, bu uygulamanın güzel bir örneğidir.(Resim 17).

17 Michael Koch, "Minton, Elkington \& Salviati : Acquisitions Made by the Bayerisches Nationalmuseum at the Vienna Exhibition 1873", The Journal of Decorative Arts Society 1850- the Present, 1992, no. 16, p. 62-75. 

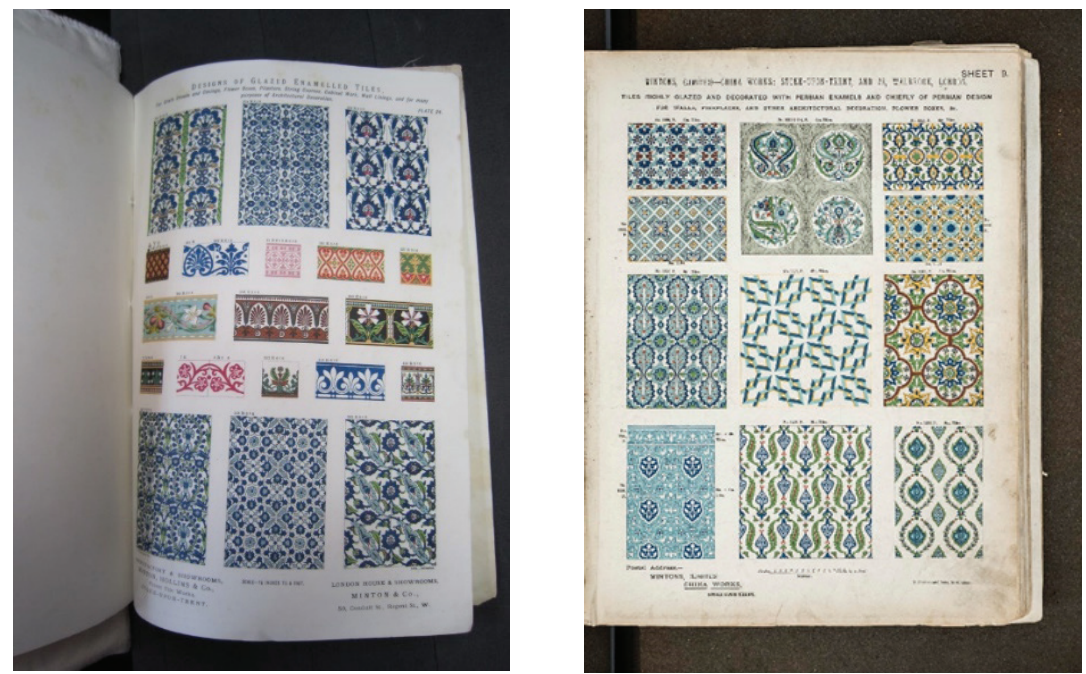

Resim 1-2. Minton kataloğunda yer alan İznik çini desen örnekleri
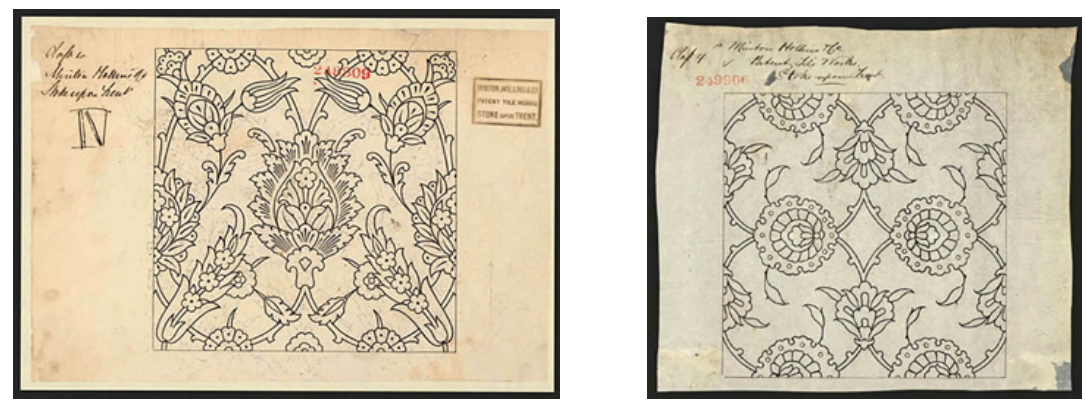

Resim 3-4. Patent alınmış çini deseni örnekleri
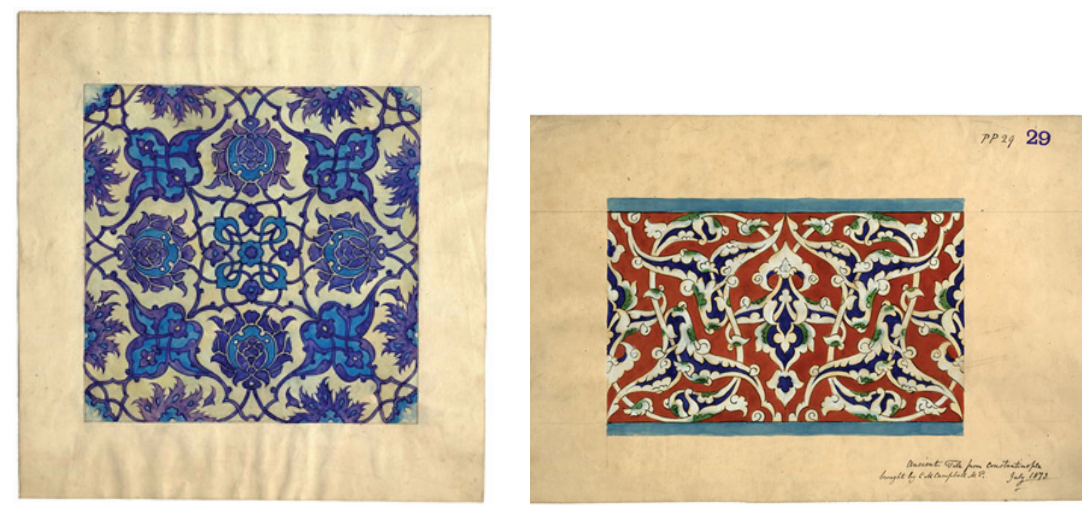

Resim 5-6. Minton arşivinden İznik çini deseni örnekler 

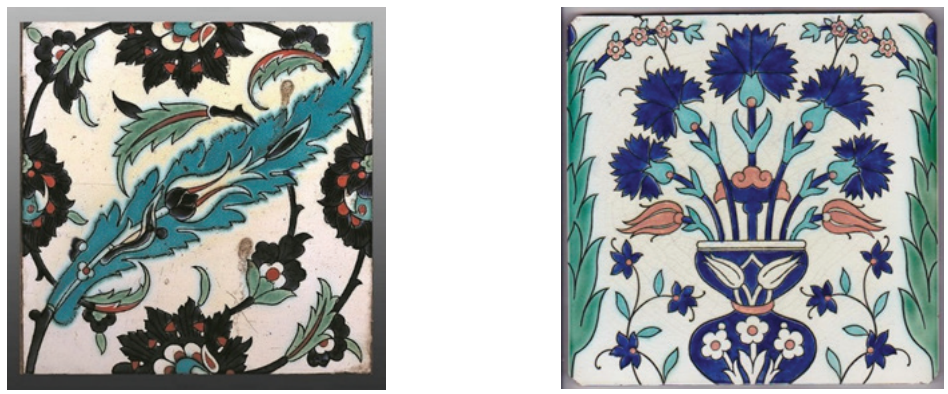

Resim 7-8. Hertford House dekorasyonunda kullanılan Minton çinileri
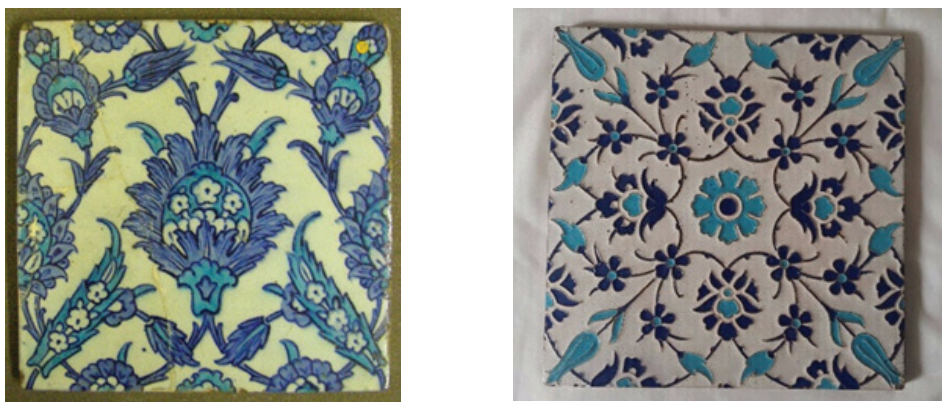

Resim 9-10. Bavyera Ulusal Müzesi tarafından satın alınan Minton çini örnekleri

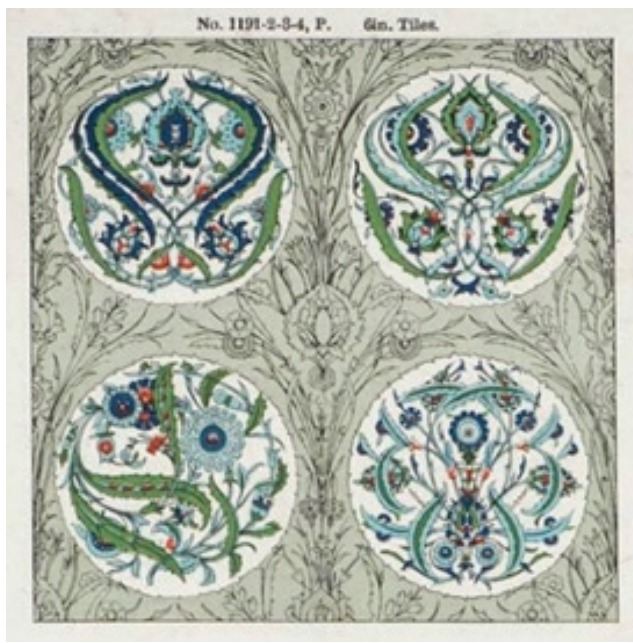

Resim 11. Bavyera Ulusal Müzesi tarafından satın alınan

Minton çini örnekleri 

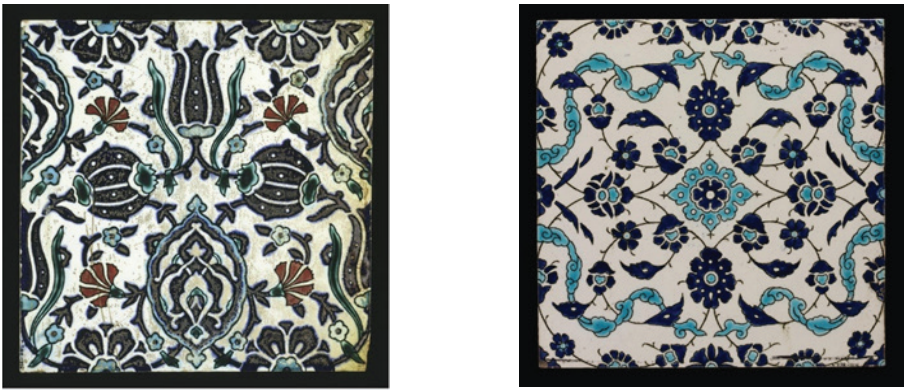

Resim 12-13. Viktorya \& Albert Müzesi koleksiyonunda yer alan Minton çinileri
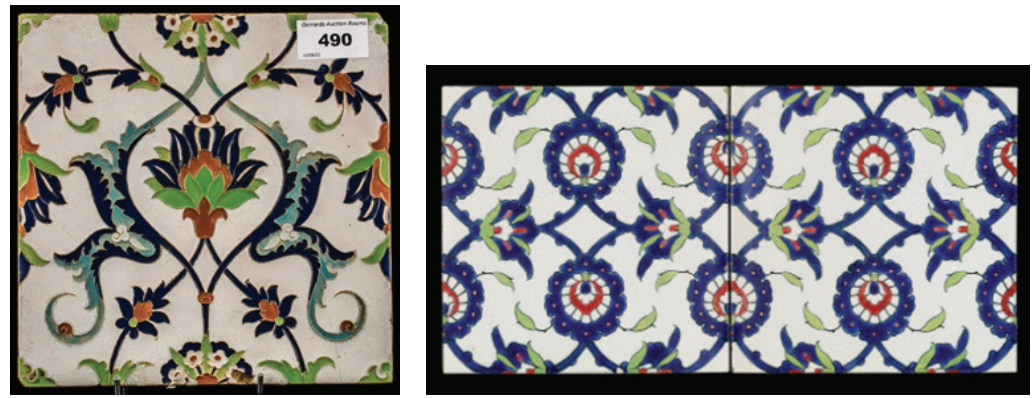

Resim 14-15. İznik deseni replikası olarak üretilmiş Minton çinileri
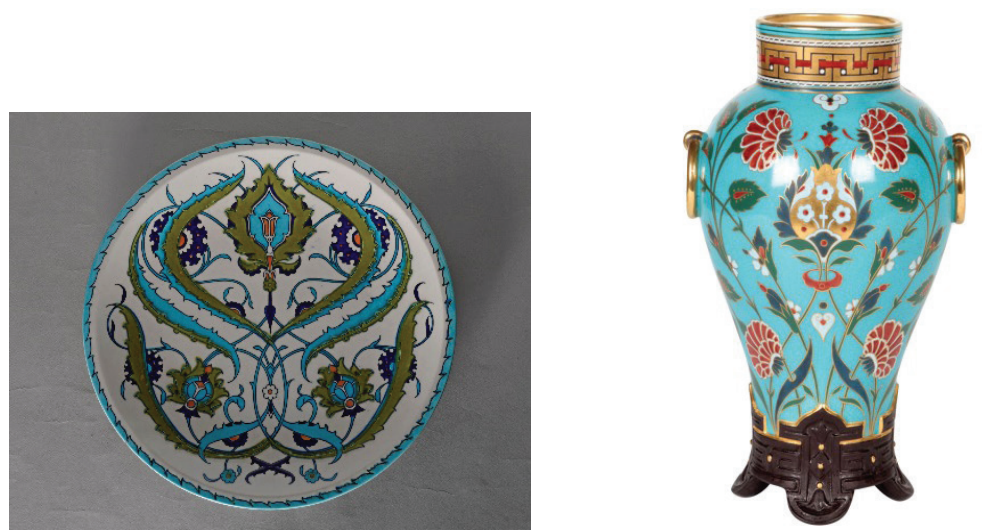

Resim 16-17. Minton üretimi İznik desenli tabak ve Cloisonné vazo 


\section{Değerlendirme ve Sonuç}

Sanayi Devrimi dönemi İngiltere'sinde seramik sektörü de yeni icatlar ve üretim yöntemlerinin hayata girmesi ile hızlı bir şekilde büyümüş, buna bağlı olarak çini ve seramiklerin seri üretim teknolojisine uygun yeni gövde yapıları ve dekor teknikleri geliştirilmesi ihtiyacı doğmuştur. Hem teknik gelişmeler, hem de tasarım konusunda yeniliklere açık olan Minton şirketi, tasarımcılar ve teknisyenlerin incelemesi için farklı kültürlerin çini ve seramiklerinden büyük bir koleksiyon oluşturmuştur.

Minton, eski kültürlere ait çini ve seramiklerin altyapısı ve tasarımlarını yeniden canlandırmak üzere en çok çaba sarf etmiş olan İngiliz üreticisidir. Eşsiz bir vizyon sahibi olan Herbert Minton, geçmişin sanatını yeni tür seramik ürünlere entegre etmek için hem teknik hünerden, hem de estetik yetenekten yararlanmıştır. Minton, Fransız ve İtalyan Rönesans seramiklerinin İngiliz versiyonlarını geliştirmek için üretim kaynaklarını Fransız kimyager ve mühendis Leon Arnoux'un deneyimiyle birleştirmiştir. Sevr'de seramik üretimi deneyimi olan Arnaux, 1848 'de İngiltere'ye gelmiş ve 1892'de emekli olana kadar Minton şirketinde sanat yönetmeni olarak kalmıştır. Arnoux, Minton'un çini gövde yapısını geliştirdiği gibi yeni sırlar ve renkler üretmiştir. 1849'da geliştirdiği İngiliz mayolikası,1851'deki Büyük Fuar'da sergilenmiş ve büyük beğeni toplamıştır. Bunun üzerine pek çok İngiliz firması, bu türdeki kendi ürünlerini üretmiştir. ${ }^{18}$

1858'de amcasının yerine geçen Colin Minton Campbell'ın mülkiyeti altıdaki şirket, egzotik kültürlerin zengin dekoratif motifleri ve cezbedici renklere sahip tasarımlarından ilham alan Estetik Hareketi'nin uzman üreticisi olarak tanınmıştı. Bunların arasında dünya müzelerinin en seçkin koleksiyonları arasında yer alan İznik çini ve seramikleri de yer almaktadır. İznik ürünlerinin desenleri hem birebir kopya olarak, hem de şirketin yetenekli tasarımcıları tarafından yorumlanmak suretiyle müşterilerin beğenisine sunulmuştur.

Minton üretimi sırlı duvar karolarında, Osmanlı mimari yapılarının çini bezemelerinde de görülen dört yandan birbirine eklendiğinde kendini sonsuz olarak türeten "ulama" tarzında desenler görülür. ${ }^{19}$ Karoların ortalama ebatları $20.5 \times 20.5 \mathrm{~cm}$. ve kalınlıkları yaklaşı $1 \mathrm{~cm}$.' dir. Resim 8, 9 ve 10'daki örneklerin tescil tarihi 26 Ocak 1871 olarak tespit edilmiştir. Teknoloji olarak seri üretimi mümkün kılan toz presleme ve transfer baskı ile dekorlama yöntemleri uygulan-

18 Ateş Arcasoy, “Araştırıcı Girişimcilerin Kurduğu Endüstri. İngiliz Porselenleri”; https://antikalar.com.

19 Sitare Turan, İznik Çinileri ve Gülbenkyan Koleksiyonu, Ankara, Kültür Bakanlığı Yayını, 1999, s. 216-227. 
mıştır. Her bir karonun arkasında sıvaya daha iyi tutunması için kaset şeklinde bölmeler ve kabartma olarak firma adı yer almaktadır.

Resim 5'te görülen ulama tarzındaki çininin benzeri, Paris'in $20 \mathrm{~km}$. kuzeyinde bulunan Chateau d'Ecouen (Musee National de la Renaissance) koleksiyonunda 15439-e envanter numarası ile yer almaktadır. C. M. Campbell tarafindan Paris'ten satın alındığı bilgisi tespit edilen karo bu olmalıdır. Resim 6'da görülen bordür karosunun aynısı ise İstanbul Ramazan Efendi Camii ve Topkapı Sarayı 3. Murad Odası çini dekorunda bulunmaktadır. Resim 8 ve 14'de görülen karoların aynıları Ayasofya 1. Mahmud Kütüphanesi çinilerinde göze çarpar. Resim 9, 10 ve 12 de görülen 17. yüzyılın karakterini yansıtan mavi-beyaz çinileri ise bu dönemin en görkemli çinili yapısı olan Eminönü Yeni Cami'de görmek mümkündür.

Minton ve diğer İngiliz firmalarının seri üretim ilkelerini benimsemesi sayesinde, sanayi devrimi öncesinde sadece varlıklı kişilerin satın alabildiği seramik ürünler, yeni alıcı kitlelerine ulaşmış ve pazar büyümüştür. Fakat ne yazık ki seri üretimle imal edilen bu ürünler, orijinallerinin kalitesine hiçbir zaman ulaşamamıştır. 


\section{Kaynakça}

Adıgüzel, Hatice, Topkapı Sarayı'ndaki Avrupa Çinileri'nin Üretim Merkezleri Işı̆̆ında Değerlendirilmesi”,

(Yayımlanmamış Doktora Tezi), İstanbul Üniversitesi Sosyal Bilimler Enstitüsü, İstanbul, 2014.

Arcasoy, Ateş, “Araştırıcı Girişimcilerin Kurduğu Endüstri. İngiliz Porselenleri"; https://antikalar.com.

Durbin, Lesley, "Nineteenth Century Tiles. Industrial Mass Production and Construction Methods of Interior Tile Schemes in the Nineteenth and Early Twentieth Centuries", Architectural Tiles Conservation and Restoration From the Medieval Period to the Twentieth Century, New York, Routledge, 2011.

Fortnum, Charles Drury Edward, A Descriptive Catalogue of the Maiolica, Hispano-Moresco, Persian, Damascus and Rhodian Wares in the South Kensington Museum with Historical Notes, Marks \& Monograms, Chapman Hall, 1873.

Gibson, Melanie, "Colouring the Surface : A Taste for Persian Tiles in English Domestic Architecture 1870-1914", Art, Trade and Culture in the Islamic World and Beyond, Gingko Library, 2016.

Hagedorn, Anette, "Orientleştirici Stilde Avrupa Cam ve Seramiği”, İslam 'da Bilim ve Teknik, (içinde), cilt 1, Ankara, Türkiye Bilimler Akademisi Yayını, 2008.

Harvey, Wendy, "A Brief History of Transfer Printed Tiles", Transferprint Collectors Club Bulletin, vol. xii, no. 1, 2011.

Koch, Michael, "Minton, Elkington \& Salviati : Acquisitions Made by the Bayerisches Nationalmuseum at the Vienna Exhibition 1873", The Journal of Decorative Arts Society 1850- the Present, 1992.

Lemmen, Hans van, "From Over Glaze to Under Glaze : British Transfer Printed Tiles 1756-1854", Journal of the Tiles \& Architectural Ceramics Society, vol. 23, 2017.

Lemmen, Hans van, 5000 Years of Tiles, London, British Museum Press, 2013.

Oshinsky, Sara J., "Christopher Dresser (1834-1904)", In Heilbrunn Timeline of Art History, New York, The Metropolitan Museum of Art, 2000.

Pearson, Lynn., "Decorative Tile and Terracotta Exports by British Manufacturers,1840-1940", Journal of the Tiles \& Architectural Ceramics Society, vol. 11, 2005. 
Thomas, John, "The Pottery Industry and The Industial Revolution", Economic History, vol. 3, no. 12, February 1937.

Turan, Sitare, İznik Çinileri ve Gülbenkyan Koleksiyonu, Ankara, Kültür Bakanlığı Yayını, 1999.

Uçar, Aygül, Karosiman : İzmir Konutlarında Döşeme Karoları, İzmir, İzmir Büyükssehir Belediyesi Kent Kitaplı̆̆ı, 2015.

Wedgewood, Josiah C., Staffordshire Pottery and It's History, London, S. Low, Marston \& Company Limited, 1913.

Y1lmaz, Ersoy, "Seramik ve Transfer Bask1 1750-1900”, Sanat ve Tasarım Dergisi, 1(10), 2012.

\section{Internet Kaynakları}

https://en.wikipedia.org/wiki/Mintons

https://themintonarchive.org.uk

\section{Görsel Kaynakları}

Resim1, 2 http://printedbritishpotteryandporcelain.com

Resim 3, 4 https://nationalarchives.gov.uk

Resim 5, 6 https://themintonarchive.org.uk

Resim 7 http://printedbritishpotteryandporcelain.com

Resim 8 https://www.goantiques.com/ntique-minton-hollins-48037791

Resim 9, 10 https://www.jstor.org/stable/41809200

Resim 11 https://www.jstor.org/stable/41809200

Resim 12 http://collections.vam.ac.uk/item/O278080/tile-minton-hollins-co/tile-minton-hollins/

Resim 13 http://collections.vam.ac.uk/item/O77879/tile-minton-hollins-co/tile-minton-hollins/

Resim 14 https://www.the-saleroom.com/en-gb/auction-catalogues/gerrards-auction-rooms

Resim 15 https://britishmuseum.org/collection/image/1613615504

Resim 16 https://britishmuseum.org/collection/image/1613269073

Resim 17 https://www.metmuseum.org/art/collection/search/6708 


\section{Araştırmacıların Katkı Oranı}

Araştırmanın her aşamasından yazar sorumludur.

\section{Çatışma Beyanı}

Araştırmada herhangi bir çıkar çatışması bulunmamaktadır. 
